\title{
The emergence of viewpoints in multiple perspective constructions
}

\author{
Sonja Zeman \\ LMU Munich
}

This paper tackles the question of how multiple viewpoints emerge through the interplay of different viewpoint parameters within the (i) dynamics of discourse and (ii) their diachronic development. In particular, it will focus on 'Future of Fate' (FoF) (e.g. He was never to return.), i.e. future-in-the-past meanings with potentially distinct values both on the semantic dimension of temporality and the dimension of knowledge attribution. These viewpoint meanings are 'irregular' in the sense that they cannot be predicted solely on the basis of the grammatical context of past modal obligation. Based on empirical analyses of German sollte + inf. and the méllo construction in Homeric Greek, it is shown that the - diachronic as well as synchronic emergence of viewpoints is the result of the interplay between the deictic structure of grammatical elements and the perspectival structure of discourse context.

Keywords: perspective, narrativity, modality, epistemicity, evidentiality, future-of-fate, subjectification

[...] multiplicity of viewpoint is the norm, not the exception. (Dancygier and Vandelanotte 2016,13)

\section{Multiple perspectives and ubiquity of viewpoints - some basic premises}

In real life, our eyes are commonly restricted to one perspective only. If one stands in front of a building, one is able to see only its fore- but not its backside, and there cannot be more than one "up" in a given situation. In symbol systems, by contrast, it is possible to present more than one perspective at a time. Multiperspectival pictures like those by M.C. Escher, to name just one example, manage to integrate irreconcilable viewpoints in a single picture but nevertheless seem to be a correct representation when seen as a whole. The following 
observations are based on the premise that in language, multiple viewpoints are the rule rather than the exception. This hypothesis has already been put forward by Sweetser (2012), Dancygier (2017), Verhagen and van Duijn (forthcoming, and this issue), Vandelanotte (this issue), and Dancygier and Vandelanotte (2016) who have shown that "seemingly 'innocent' or 'viewpoint-neutral' lowerlevel constructions" (Dancygier and Vandelanotte 2016,13) such as determiners or negation can function as viewpoint markers. Similar points have been made by Evans (2005), Vandelanotte (this issue), Spronck (2012, 2015), Si and Spronck (this issue), and Bergqvist $(2015,2017)$ in their work on multiple perspective constructions. The ubiquity of viewpoints is thus found in specific grammatical constructions as well as on the discourse level, and both aspects will be brought together in the following investigation.

A second premise concerns the notions of 'viewpoint' and 'perspective'. In the words of Sanders $(1994,37)$, 'perspective' is determined as "the introduction of a subjective point of view that ascribes the claim of validity of the presented information to a particular subject (person) in the discourse". Similarly, Dancygier and Vandelanotte $(2016,14)$ define perspectivization as "a discourse participant's alignment with an aspect of a frame or situation". In this sense, 'perspective' and 'viewpoint' constitute person-bound categories since every act of perspectivization presupposes a perspectivizing subject. In consequence, multiple perspective constructions are constructions that involve more than one 'perspectivizing subject', as also formulated in Spronck $(2015,7)$ who states that "a perspective can only be meaningfully interpreted if it is attributed to a person, and that multipleperspective constructions therefore involve at least two person values [...]". Yet, as he also highlights, it has to be kept in mind that these person values do not represent "real" physical persons in the extralinguistic world but functional roles within discourse. The same person value can therefore exhibit different referential interpretations, as detailed in enunciative theory (Benveniste 1966; Ducrot 1984) in the tradition of Bühler (1934) and Jakobson (1957). This is seen in the fact that a speaker can split himself up in a speaking and an observing subject, as in instances of self talk and first person narratives where the narrator and the protagonist denote the same "person" on the story level but referentially constitute two different instances within the text which usually hold different states of knowledge (see Zeman 2018a).

In consequence of these two premises - the ubiquity of multiple viewpoints in grammatical markers and the differentiation of functional roles - it is thus the relationship between the different viewpoints that becomes a main object of investigation. In this respect, Dancygier and Vandelanotte $(2016,14 \mathrm{f}$.) have proposed to investigate the relations between viewpoints in terms of mental space theory as network constellations. In these constellations, viewpoints are seen as hierarchi- 
cally ordered mental spaces and can be linked to embedded, parallel, alternative or independent spaces. Similarly, in the account by Verhagen and van Duijn (this issue), perspectives are modelled as "thoughtscapes", i.e. as networks of different but related mind states. What yet remains an open question is how the different viewpoints emerge and how they interact within these network constellations.

In order to address this question, the present article addresses the emergence of multiple perspective constructions and their interaction within the dynamics of discourse and in the course of their diachronic development. The focus is on one particular grammatical element - or more precisely: its perspectival interpretation -, namely on modal markers with a Future-of-Fate (FoF) reading. Section 2 will show that these readings constitute multiple perspective constructions in the sense of Evans (2005) but could be seen as 'irregular' in that they only arise in certain contexts, and are therefore not predictable solely on the basis of the grammatical forms with which they are associated. Section 3 focuses on the grammatical pattern of the German modal verb sollte ('should') + inf. in comparison to the semi-auxiliary émelle ('intended to') + inf. in Homeric Greek in order to isolate the different grammatically encoded and context-dependent factors that trigger the emergence of multiple viewpoints. The comparison is complemented by a diachronic investigation of sollte + inf. from Old High German to Modern High German in Section 4 which shows that the FoF readings are already present in older stages of German. The analysis thus suggests that the emergence of the FoF reading is - synchronically as well as diachronically - the result of the interaction between the source semantics of the past modal verb and its interaction with different factors of discourse. This will allow for insights with respect to the general mechanisms of the emergence of multiple viewpoints and viewpoint interaction (Section 5).

\section{Future-of-Fate readings as multiple perspective constructions}

Future-of-Fate (FoF) readings are proleptic structures restricted to narratives that give an outlook on the events to come in the future of the story line, see the German modal verb construction sollte ('should') + infinitive in (1).

(1) Er sollte niemals aus Neapel zurückkehren.

'He was never to return from Naples.'

Next to a future-in-the-past meaning, (1) also indicates a divergence between the narrator's and the character's knowledge in form of the pattern 'it is a safe fact known to the narrator that event $\mathrm{x}$ will happen in the following course of the story, whereas this is not a content of the focalized protagonist's knowledge'. Such 
readings are promising objects of investigation both with respect to the mechanisms of the emergence of multiple viewpoints and viewpoint interaction.

First, FoF interpretations display multiple perspectives in a double sense in terms of Evans (2005). According to Evans $(2005,99)$, multiple perspective constructions are "constructions that encode potentially distinct values, on a single semantic dimension, that reflect two or more [...] distinct perspectives or points of reference". With respect to the FoF readings, the different values concern both the semantic dimension of temporality and the dimension of knowledge attribution, as outlined in $\left(1^{\prime}\right)$.

$\left(1^{\prime}\right)$ Er sollte niemals aus Neapel zurückkehren.

'He was never to return from Naples.'

a. Semantic domain: temporality

Distinct perspectives: time of speech, time of story now

Distinct values: story-now in the past, future

b. Semantic domain: epistemicity

Distinct perspectives: narrator, character

Distinct values: known, unknown

Furthermore, FoF readings integrate both a 'metaperspective', i.e. "a secondary perspective [that] is located with respect to a primary one" (Evans 2005,96) and a 'double perspective', i.e. an "independent calculation of values from two independent perspectives or standpoints" (Evans 2005,97).

(1") Er sollte niemals aus Neapel zurückkehren.

'He was never to return from Naples.'

Metaperspective: 'Narrator presents as certain $\mathrm{p}$ [he won't return from Naples].'

Double perspective: ' $\mathrm{N}_{\text {arrator }}$ knows that p'.

'Character does not know that p.'

Second, the perspectival complexity of FoF interpretations arises only in certain instances and could thus be supposed to be 'irregular' - both in comparison to the deontic meaning (DMV) in ( $2 b$ ) and the epistemic meaning (EMV) of the modal verb in (2c), the latter being reinforced by the atelic infinitive complement (see Abraham 2008 with respect the cross-linguistic link between imperfectivity and epistemicity):

(2) a. Er sollte in drei Tagen zurückkehren.

'He was to return in three days (because this was his destiny).'

$\rightarrow$ FoF

$\rightarrow \mathrm{N}_{\text {arrator }}$ predicts for certain $\mathrm{p}$ [he will return in three days]

$\rightarrow$ Event realization: certain 
b. Er sollte in drei Tagen zurückkehren.

'He was obliged to return in three days.'

$\rightarrow{ }^{*} \mathrm{FoF} / \mathrm{DMV}$

$\rightarrow \mathrm{p}$ [he had the obligation to return in three days]

$\rightarrow$ event realization: unspecified

c. Er sollte (wohl) in drei Tagen zurück sein.

$\rightarrow{ }^{\star} \mathrm{FoF} / \mathrm{EMV}^{1}$

'He will be back in three days - I assume.'

$\rightarrow \mathrm{S}_{\text {peaker }}$ or $\mathrm{N}_{\text {arrator }}$ assumes based on some given plan $\mathrm{p}$ [he will be back in three days]

$\rightarrow$ Event realization: uncertain

In consequence, the question arises which factors elicit the multiperspectival reading in the dynamics of discourse. With respect to the mechanisms of viewpoint interaction, this question is worth pursuing for two reasons: First, it provides insights into the process of viewpoint disambiguation in discourse. Second, it offers insights into the principles of viewpoint emergence on the diachronic and synchronic level.

\section{Emergence of viewpoints in FoF readings - the synchronic dimension}

In order to uncover the factors that trigger the multiple perspectives in FoF readings, the following section takes a closer look at the grammatical semantics of German sollen ('shall') + inf. and the semi-auxiliary méllō ('intend') + inf. in Homeric Greek. The analysis of German sollte + inf. is based on a diachronic corpus study in the Kali-Corpus (covering eight centuries of the Old High German and Middle High German periods), Otfrid's Evangelienbuch for Old High German, three classic epic poems of Middle High German (i.e. The song of the Nibelungs; Perceval by Wolfram von Eschenbach; War of the Trojans by Konrad von Würzburg), the DTA (1600-1900) and the DWDS Kernkorpus (2000-2010) comprising fictional, scientific and newspaper texts. In order to detect the disambiguation patterns, the

1. It is controversial (i) whether instances of sollte + inf. like in (2c) are comparable to (2a-b) because they are commonly interpreted as conjunctive mood ('Konjunktiv II') (see also Section 3.1) and (ii) whether they are epistemic at all, see for discussion Diewald $(1999,203)$ who argues that such instances of sollte + inf. can be interpreted as epistemic ('deictic' in her term) due to their mixture of deontic and conditional meaning, but do not display an evaluation of the speaker with respect to the factuality of the proposition. In this sense, (2c) would not presuppose a speaker but only give a description of the fact 'if a certain condition is given, then it is necessary that he will be back'. See also Section 4 for a discussion on the relationship between FoF and epistemicity. 
corpus analysis was furthermore supplemented by an analysis of the instances of méllo in the Iliad and the Odyssee and a search for minimal pairs (i.e. instances of sollte with the same infinitive complement and/or temporal adverbials but different interpretations) on www.google.de. The results are furthermore set in relation to constructions in other languages which are described in the literature as displaying a similar FoF-effect.

\subsection{The semantic pattern of 'sollte' + inf.}

As already indicated above, the FoF-reading of sollte + inf. is a 'special case' in terms of semantics (Glas 1984, 99f.; Öhlschläger 1989, 176) since it denotes a high degree of certainty with respect to a future event realization, which is uncommon both for the deontic and epistemic reading of modal verbs (cf. Example (2) above). In order to describe the grammatical semantics of sollte + inf., it is necessary to look at the semantic components of the form, i.e. (i) the modal verb soll- ('shall') and (ii) the suffix -te. Its morphology is not completely transparent since the uses of the form sollte for both the indicative preterite and the subjunctive mood ('Konjunktiv II') are homophones since the Middle High German period. In the literature, it is sometimes assumed that the subjunctive form sollte has gained a completely new meaning and split into a lexeme different from the modal verb sollen (see Diewald 1999,198 for critical discussion and an argumentation in favor of a compositional account). According to Fritz (1997), this split however did not occur before 1600, which means later than the first occurrences of FoF readings. The early examples in Old High German discussed in Section 4 - i.e. examples from a period where indicative (scolta) and subjunctive (scolti) in third person are still morphologically distinguished -, suggest that the form carrying a FoF reading can be compositionally analyzed as an indicative preterite form of sollen, which would also be in line with the cross-linguistic comparison (see Section 3.2).

With respect to the semantic contribution of the modal verb soll-, traditional accounts describe the FoF reading as an isolated relic which goes back to an older periphrastic use to denote future tense reference (see Gloning 2001; Fritz 1997, 46). This hypothesis remains, however, insufficient for two reasons. First, Old High German skulan and Middle High German suln do not grammaticalize into a future tense marker but generally retain their modal meanings in all stages of German (see Diewald and Habermann 2005; Zeman 2013; Abraham and Nishiwaki 2016). Second, the future relict hypothesis offers no explanation for the high degree of certainty as the major component of its semantics: Since future events are inherently unknown, reference to the future commonly implies uncertainty on behalf of the speaker (see e.g. Dahl 2006 for an overview on the cross-linguistic link between future temporality and epistemic uncertainty). 
Furthermore, the traditional account only focuses on the future realization of the event while neglecting the complex viewpoint constellation, see (3).

\section{(3) Wenige Stunden später sollte sie eine böse Überraschung erwarten.}

'A couple of hours later, a nasty surprise should await her.'

[https://www.welt.de/vermischtes/article166697218/Dieb-klaut-Fahrrad-

Besitzerin-stiehlt-es-sich-zurueck.html; 01.08.2017]

With respect to its temporal value, (3) displays a 'future-in-the-past' reading that refers to a future event seen from the perspective of the 'story-now', while the verbal event is, at the same time, past as seen from the perspective of the point of speech. This double temporal constellation can be derived from the deictic structure of the modal verb construction and the past marker. First, the projective reading is an inherent semantic feature of the modal verb. As is well known, modal verbs like suln + inf. are biphasic constructions since they integrate two different time intervals: The time interval of the deontic modal $\left(\mathrm{I}_{\text {MODAL }}\right)$ (i.e. the time for which the obligation is valid), and the time interval covered by the event that should be realized, denoted by the infinitive $\left(\mathrm{I}_{\text {EVENT }}\right.$ ) (see Abraham 2008; Maché 2008, 403f.; Depraetere 2012, 990f.; Zeman 2014). In combination with telic infinitive complements, the deictic structure thus offers the potential for two different temporal reference points. In addition, the past marker denotes a distance between the time interval of the modal and the time of speech, so that in consequence three temporal reference points arise, allowing for three different viewpoints (i.e. the narrator's, the protagonist at the 'story-now', and the protagonist in the future).

These viewpoints are however not equivalent alternatives, but are situated on different levels of the hierarchically ordered discourse structure, as seen in the fact that the narrator's knowledge includes both the knowledge state on the level of the characters and the knowledge about the further line of discourse. This hierarchy allows for the unexpected combination of a future meaning and a high degree of certainty with respect to the actualization of the future event. Uncertainty is ruled out with the emergence of the narrator's viewpoint on a higher level. ${ }^{2}$

2. A reviewer raised the intriguing question whether FoF readings present an exception for Verstraete's (2005) cross-linguistic rule of composite mood marking, derived from his investigation on mood-marking in non-Pama-Nyungan languages of northern Australia. Verstraete argues that modal meanings of the past are inherently weaker on the scale of information than their non-modal equivalents and lead to the pragmatic implicature of non-actualization and, based on that, counterfactuality: "Using the epistemically weaker expression of potentiality will trigger the implicature that there was a reason not to use the stronger non-modal expression, i.e., that the event did not take place." (Verstraete 2005,236) Taking into account the temporal structure and viewpoint constellation, the FoF reading of sollte is however not an exception to 
All in all, the FoF reading of the past form can be analyzed by decomposing it into its core semantic components, which show the result of two different viewpoint splits. First, the biphasicness of the modal verb allows for a horizontal shift on the propositional level with the 'story-now' as reference point, leading to a potential difference between two different temporal instances of the protagonist, i.e. the protagonist carrying an obligation at the story-now (expressed in the modal verb), and the protagonist at the time of the future realization of the event to be carried out (as expressed in the infinitive). Furthermore, there is a vertical shift leading to the emergence of a narrator's level above the proposition. As will be seen in the next section, this grammatical pattern can also be observed for the source constructions of other FoF constructions in different languages.

\subsection{The semantic pattern in crosslinguistic comparison}

Seen from a cross-linguistic point of view, FoF readings are fairly unremarkable insofar as they are also documented in other languages. Next to modal verbs that etymologically trace back to the semantics of obligation like English should, Danish skulle and Swedish skulle (see Zeman 2018b), a similar pattern can also be observed for the méllō ('intend') + inf. construction in Ancient Greek. Méllō + infinitive is commonly classified as a (semi-)auxiliary that denotes a "present intention of the subject of the realization of a state of affairs in the (near) future" (Wakker 2006), see (4).

Verstraete's rule. A past modal per se seems not enough to trigger the implicature, as the examples in Verstraete (2005) suggest, that it is necessary that the time interval of the event is before or simultaneous to speech time (compare 'You should have shot it ( $\rightarrow$ but he didn't)' and 'You should be shooting it ( $\rightarrow$ but you aren't')' vs. 'You should shoot it', where no implicature is triggered regarding the actualization of the event). This is also in line with the semantic map for the modal uses of Polish mieć in Holvoet $(2012,144)$, where 'unrealised intention' is supposed to lead to counterfactual uses, but not the 'destiny type'. Seen within a bigger picture, this calls for further cross-linguistic work in perspectival terms in order to specify in greater detail the grammaticalization pathways. 


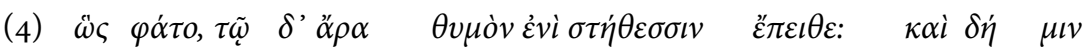
hòs fáto tō:i d'ára thumòn enì sté:thessin épeithe kaì dé: min so said him PTCL PTCL mind in his breast persuaded and PTCL him $\tau \dot{\alpha} \chi \chi^{\prime} \ddot{\varepsilon}^{\prime \prime} \mu \varepsilon \lambda \mathcal{\varepsilon}$

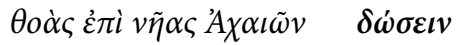
tákh' émelle thoàs epì nē:as Akhaiō:n dó:sein soon intend-3sG.IMPF.ACT to Achaeans' swift ships give-INF.FUT $\tilde{\omega} \theta \varepsilon \rho \alpha \dot{\pi} \pi o v \tau \iota \quad \kappa \alpha \tau \alpha \xi \dot{\varepsilon} \mu \varepsilon v$ : hō:i theráponti kataxémen to the companion to.lead.down 'So he said and tried to persuade his heart; and he was about to give him to his companion to lead to the swift ships of the Achaeans' [Iliad 6.52]

In (4), émelle refers to Menelaus' intention not to kill Adrestes. Méllein denotes the subject's mental state of thinking about doing something whereas it is not determined whether the intended action will indeed be realized in the course of the story or not (in fact some lines later, Agamemnon will have changed Menelaus' mind). (5), in contrast, evokes a FoF reading. The realization of the event in the future is presented as affirmed as certain whereas the intention of the subject is not at issue or even contradicted:

(5) ov̉ $\delta^{\prime} \quad \ddot{\alpha} \rho ' \quad z \mu \varepsilon \lambda \lambda \varepsilon v$

$\dot{\varepsilon} \lambda \theta \dot{\omega} v \dot{\varepsilon} \kappa v \eta \tilde{\omega} v \quad \ddot{\alpha} \psi^{\prime \prime} E \kappa \tau o \rho l$

oud' ár' émellen elthò:n ek ne:ō:n áps Héktori

but not PTCL intend-3SG.IMPF.ACT come from the ships back to.Hector

$\mu \tilde{v} \theta o v \quad \dot{\alpha} \pi o i \sigma \varepsilon \imath v$.

mūthon apoísein

report to.bring.back-INF.FUT

'but in fact he was never to return [ ${ }^{*}$ did not intend] from the ships and to bring his report back to Hector'

(translation by de Jong 2007,25) [Iliad 10.336]

In (5), the construction indicates what will happen in the future course of events against the will of the subject; it is clear from the context (and the common knowledge of the audience) that it is not Dolon's intention not to return. Méllein + inf. thus invokes the same complex perspectival constellation as sollte + inf. and refers to a time interval that is posterior to a reference point that is already past as seen from the perspective of the narrator. By speaking about the events to come, the construction does not only refer to the propositional but also to the non-propositional level, ${ }^{3}$ i.e. it does not only describe the relations between the

3. There are different terms used in the literature denoting the difference between the propositional vs. the non-propositional level, such as e.g. the distinction between descriptive and 
states of affairs in the represented world, but also their relation to the representational discourse level.

Sollte + inf. and émellen + inf. thus display a very similar semantic pattern. Both sollen ('shall') and méllein ('intend to') + inf. are biphasic constructions which involve two different temporal reference points. While the time interval of the modal includes the subject's present, the realization of the event denoted by the infinitive will take place (or not) after the present reference point. In this respect, méllō just as sollen + inf. "inherently unites, then, two different semantic notions: present intention/arrangement and (relatively) future realization" (Wakker 2006, 245, similarly Wakker 2007, 169). In this respect, also méllein + inf. has been discussed as an auxiliary of the future tense (see Basset 2003 [1966]; Wakker 2006, 2007; Allan 2013, 34 Fn. 44). However, similar to the German form sollen + inf., méllo + inf. seems to retain its modal semantics, see Wakker (2006, 2007) and Markopoulos (2008) who shows that méllō was "not exactly equivalent to the Future Tense, as it implied less commitment on the part of the speaker concerning the realization of the action described, in other words it was more modal than temporal" (Markopoulos 2008, 21).

Furthermore, both source constructions display a semantic core of necessity. The semantic source concept of sollen relies in the meaning 'to owe' and indicates that the subject is obliged to do something by an external source of obligation. Méllō is oscillating between different modal shades and can correspond to a whole range of modal verbs: 'a) I think, think about doing, like cogito facere, b) I shall, must do, frequently in Homer: it is destined to do something, c) I can, am able to do, d) I am allowed to do, e) I may' (Kühner et al. 1870, $\$ 387$ note 2,150$).{ }^{4}$ According to Kühner et al. (1870), the original meaning is 'think about doing something' whereby the modal force can be the subject's own will ('intend to do') or the will of a third external source (similarly also Markopoulos 2008, 21). The latter seems to be the relevant semantic component, as seen in comparison with constructions in French (Schrott 1997), Polish (Hansen 2009; Holvoet 2012), ${ }^{5}$ English (Sugayama 2006) and Spanish (Butt et al. 2013, $\$ 21.4 .1$ ) which display FoF readings, see Table 1.

interpretive use in Relevance Theory (Sperber and Wilson 1986, 228), presentational and representational (Kroon 1998) and ideational and interpersonal level (Halliday and Hasan 1976). It will be a task for future research to specify these notions more precisely in relation to the different layers of illocution in the sense of Bergqvist (2017).

4. Original wording: “(a) ich denke, gedenke zu thun, wie cogito facere, (b) ich soll, muss thun, b. Hom. häufig: es ist mir vom Schicksale beschieden Etwas zu tun, (c) ich kann, bin im Stande zu thun, (d) ich darf thun, (e) ich mag wol."

5. I am grateful to Björn Wiemer for pointing out this 'destiny type' and the relevant references to me. 
Table 1. Comparison of source constructions for FoF readings (Zeman 2018b)

\begin{tabular}{|c|c|c|c|c|c|c|}
\hline & $\begin{array}{l}\text { Ger. } \\
\text { sollte }\end{array}$ & $\begin{array}{c}\text { Agr. } \\
\text { emellen }\end{array}$ & $\begin{array}{c}\text { Fr. } \\
\text { devait }\end{array}$ & $\begin{array}{l}\text { Pol. } \\
\text { mieć }\end{array}$ & $\begin{array}{l}\text { Engl. } \\
\text { was to }\end{array}$ & $\begin{array}{c}\text { Span. } \\
\text { había de }\end{array}$ \\
\hline past marker & $\checkmark$ & $\checkmark$ & $\checkmark$ & $\checkmark$ & $\checkmark$ & $\checkmark$ \\
\hline $\begin{array}{l}\text { lexical } \\
\text { source }\end{array}$ & $\begin{array}{l}\text { 'owe' > } \\
\text { 'shall' }\end{array}$ & $\begin{array}{l}\text { 'owe' > } \\
\text { 'must' }\end{array}$ & $\begin{array}{l}\text { 'intend'/'is } \\
\text { intended' }\end{array}$ & 'have' & 'be' & 'have' \\
\hline $\begin{array}{l}\text { deontic } \\
\text { reading }\end{array}$ & obligation & necessity & $\begin{array}{c}\text { obligation > } \\
\text { necessity }\end{array}$ & necessity & $\begin{array}{c}\text { necessity, } \\
\text { arrangement }\end{array}$ & $\begin{array}{c}\text { necessity, } \\
\text { arrangement }\end{array}$ \\
\hline $\begin{array}{l}\text { epistemic } \\
\text { reading }\end{array}$ & $\checkmark$ & - & $\checkmark$ & $\checkmark$ & - & - \\
\hline $\begin{array}{l}\text { modal } \\
\text { source }\end{array}$ & $\begin{array}{c}\text { 3.ps. } \\
\text { evidence }\end{array}$ & $\begin{array}{c}\text { under- } \\
\text { specified }\end{array}$ & $\begin{array}{c}\text { 1.ps. } \\
\text { inference }\end{array}$ & $\begin{array}{c}\text { 3.ps. } \\
\text { evidence }\end{array}$ & $\begin{array}{c}\text { covert } \\
\text { modality }\end{array}$ & $\begin{array}{c}\text { covert } \\
\text { modality }\end{array}$ \\
\hline future tense & - & - & - & $-{ }^{6}$ & - & - \\
\hline biphasicness & $\checkmark$ & $\checkmark$ & $\checkmark$ & $\checkmark$ & $\checkmark$ & $\checkmark$ \\
\hline
\end{tabular}

Table 1 reveals the following similarities between the different source constructions:

1. Despite the different grammatical constructions that constitute the base for FoF readings, all of the analysed source constructions denote a semantic component of 'necessity'/'obligation', whereby the deontic source is an external force that lies outside the communicative situation. As seen for the be and have constructions, the necessity reading does not require that the obligation has been expressed.

2. None of the construction can be classified as a 'pure' future tense marker. The projective semantics results from an inherent biphasicness of the (semi-)modals which denote a present time interval of the time of obligation for an event that might be realized afterwards. The projective reading is reinforced by telic infinitives and infinitives in combination with a preposition (see Sugayama 2006 with respect to the was to construction in English; Abraham 2012 for the functional correspondence between prepositional and telic infinitives).

3. Morphologically, all constructions exhibit a past marker which seems to be a prerequisite for the dual temporal structure that integrates a prospective view on the future events of the story as seen from the 'story-now' and the narrator's retrospective view.

6. Despite the fact that mieć + inf. can refer to the future, it is commonly not seen as a future tense marker, see Łaziński (2001) for discussion. 
The semantic prerequisites for FoF-readings seem thus to be (i) projective biphasicness, (ii) an external deontic source, and (iii) past tense. This pattern does not yet explain how the FoF reading is disambiguated on the level of discourse - a question that will be addressed in the next section.

\subsection{Disambiguating factors}

In order to examine the disambiguating factors of FoF readings, we first of all have to acknowledge that these readings are restricted to narrative discourse, while non-narrative contexts elicit deontic (or epistemic) meanings, cf. (6-7).

(6) Ich sollte morgen den Artikel fertig schreiben.

$\rightarrow$ DMV

'I should/am obliged to finish the article tomorrow.'

(7) Am nächsten Tag sollte ich den Artikel fertig schreiben.

$\rightarrow$ FoF

'The next day, I should/was to finish the article.'

Narrative and non-narrative contexts differ with respect to their perspectival structure. Whereas in non-narrative discourse the speaking and observing subject are per default the same, narrative discourse is characterized by a structural difference between the narrator and character level, whereby the distinction between narrator and character level can be seen as a projection of the grammatical differentiation between speaker vs. observer, and hence, as the result of a vertical split. This double-layered structure provides a viewpoint potential that can be activated in the dynamics of discourse (see Zeman 2018c). The emerging viewpoints are hierarchically ordered, since the narrator's level includes the character/event level, see Figure 1.

\section{SPEAKER LEVEL}

IF (Illocutionary force) - Locutionary subject

$\rightarrow$ NARRATOR LEVEL

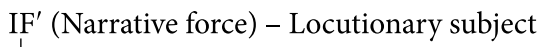

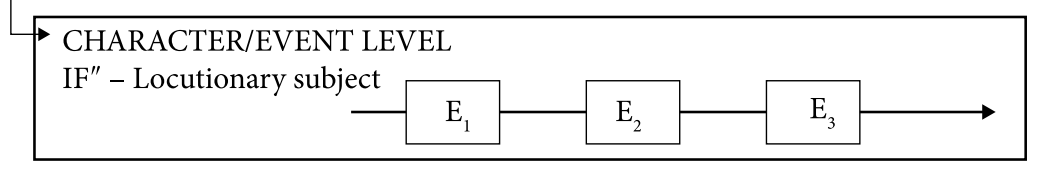

Figure 1. Viewpoint levels of narrative discourse structure (Zeman 2018c) 
Taking into account the hierarchy of perspectival structure of narrative contexts is relevant for an explanation of FoF readings in two respects. First, the hierarchical discourse structure leads to a qualitative difference between the viewpoints as seen in the fact that the knowledge of the narrator structurally includes the protagonist's knowledge but not vice versa. Second, it allows for a simultaneous activation of viewpoints on more than one hierarchical level, and hence, for the integration of both the narrator's and the protagonist's perspective which results in the knowledge asymmetry that is inherent to the FoF reading. The effects of the hierarchical structure also become obvious within the interaction between FoF reading and the perspectival constellation of the context, as seen in the fact that multiperspectival FoF readings are blocked in Free Indirect Discourse (FID), cf. the minimal pairs in (8-9).

(8) Ich wußte es besser - und klagte doch auch mit ihm.

\section{Aber ich sollte sie wiedersehen!}

Es war ein stiller Abend. [...]

[Schefer, Ludwig. 1845. Der Kuss des Engels. Verlag von Veit \& Comp.] 'I knew better - and still lamented with him. But I was to see her again! It was a silent evening. [...]'

(9) Da plötzlich erschrak ich. Wahrhafftig - wie fiel mir das erst jetzt ein - ich sollte sie wiedersehen, aber wo und wann? Sie konnte unmöglich wissen, wo ich abgestiegen war - und ich hatte mich ja bereits vergeblich nach ihr erkundigt. Stumm und ungeschickt hatte ich dagestanden, und nun, - war sie mir nicht fast so gut wie abermals verloren?

[Salomon, Ludwig. 1908. Die Blüchertrompete. B. Elischer.]

'Suddenly, I was frightened. Indeed - how did this cross my mind only now - I should see her again, but where and when? She could not possibly know where I was staying - and I had already asked after her in vain. Silently and clumsily I had stood there, and now, - wasn't she practically lost to me again?'

If no context is given, both (8) and (9) could be interpreted as FoF readings. Yet, unlike in (8), the context in (9) prevents such an interpretation. In this context of Free Indirect Discourse, the character's point of view constitutes the reference point for linguistic elements of perspectivization like deliberative questions (aber wo und wann?), evaluative expressions (Wahrhafftig, vergeblich), modal particles ( $j a$ ) and pauses of reflection, indicated by the dashes in the text (see for the characteristics of Free Indirect Discourse Banfield 1982; Fludernik 1993; Eckardt 2014). In FID, the viewpoint is thus located at the protagonist's level, while the narrator's viewpoint is disabled (cf. also Vandelanotte, this issue on the relation of FID to (irregular) perspective structure). In consequence, the perspectival context of FID is incompatible with a FoF reading since the viewpoint positioning does not allow 
for any activation of its dual structure. In this respect, FoF and FID display two complementary perspectival structures that are reverse to each other.

The examples also show that the high degree of certainty which is a characteristic semantic component of FoF readings is linked to the nature of the hierarchical viewpoint structure, since it emerges as a result from the narrator's authority and controlling force on the discourse, which rules out any intervention of the character on the story level. This authority is thus not linked to any mental consciousness but emerges structurally from the 'external', i.e. higher discourse level.

On the content level, the disambiguation of viewpoints can be supported by indications that the future realization of the event lies outside the control of the focalized character, i.e. the most prominent mental subject in the story that constitutes the reference point for narrative perspectivization. In prototypical examples, contrasts between the character's intention and the narrator's knowledge indicate that the event realization lies outside the control of the protagonist. In (5) above, for instance, the events will happen against the will of the protagonists: Dolon intends to come back to the Trojans, but he cannot change his destiny. On the linguistic level, this correlates with a high number of passive and impersonal constructions that accompany FoF readings (see Zeman forthcoming).

With respect to the synchronic disambiguation, it thus becomes obvious that the FoF reading is not triggered by any formal markers but is a result from the interaction between the deictic pattern and the perspectival structure of discourse context.

3.4 Interim conclusion: Disambiguating factors and the emergence of viewpoints

The cross-linguistic comparison of FoF readings has thus shown that the emergence of viewpoint complexity relies on the interaction of the following parameters:

\section{Viewpoint potential}

FoF readings are the result of the interaction between the deictic structure of the source construction and the perspectival structure of discourse context. The emergence of the narrator's viewpoint can be seen as the result of the activation of a covert viewpoint potential provided by the narrative context.

2. Hierarchy of viewpoints

The emergence of the narrator's viewpoint is the result of a vertical split, which leads to a hierarchy of viewpoints. This is seen in the fact that FoF readings are blocked in contexts where a vertical split between speaker and evaluator or narrator and character is suppressed, as e.g. in Free Indirect Discourse. 


\section{Contrasting perspectives}

The disambiguation of FoF readings on the discourse level is supported by potential contrasts of truth-incompatible perspectives on the level of propositional content, i.e. for example, the beliefs of two mental subjects as alternative, contrasting viewpoints.

What the examples of FoF readings thus make obvious is that perspectivization as a discourse phenomenon is much more than 'perspective taking' in terms of perspective shifts. As has been shown before, the emergence of viewpoints is based on several micromechanisms of perspectivization (Zeman 2017) rather than a simple viewpoint shift. This is the case both with respect to the emergence of multiple perspective readings of grammatical constructions as well as to the emergence of multiple viewpoints on the discourse level, as illustrated in Figure 2. While alternative viewpoints (i) are the prerequisite for any act of perspectivization, the case of FoF readings displays a more complex situation by presupposing not only a viewpoint shift on the horizontal axis, i.e. between two viewpoints functioning at the same level with respect to the perspectivized element, (ii) but also a viewpoint hierarchy as a result of a vertical viewpoint shift (iii). This hierarchical viewpoint setting is the prerequisite for the metaperspectival constellation and the integration of divergent viewpoints at the same time.

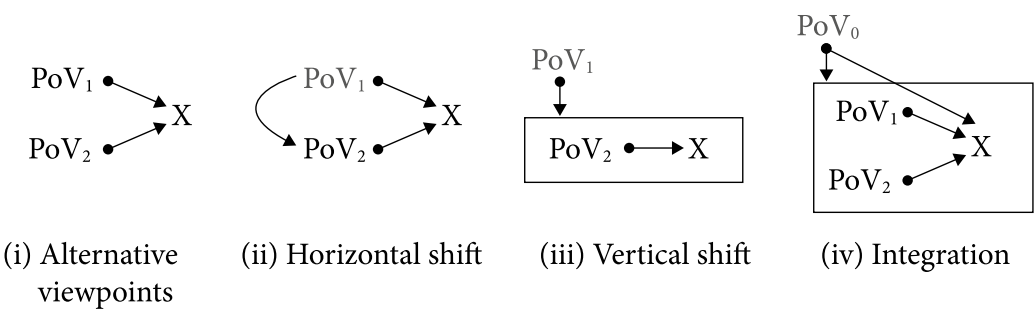

Figure 2. Emergence of viewpoints in multiple perspective constructions (Zeman 2017)

In consequence, it seems inadequate to describe the disambiguation of FoF readings in terms of perspective 'shifts' in sense of (ii). Rather, it is the result of the interplay between the perspectival structure of the grammatical source construction and the perspectival structure provided by context. As seen in the next section, this is also supported by a diachronic look on FoF readings.

\section{Emergence of viewpoints - The diachronic dimension}

As seen above, FoF readings are the result of a vertical shift that leads to the emergence of a narrator's viewpoint which scopes over the whole proposition. In this 
sense, FoF readings seem to display 'subjective' meanings in the sense of Traugott $(1989,2010)$ in that they indicate a "SP/W subjective belief state or attitude toward what is being said and how it is being said" (Traugott 2003,125). In consequence, the question arises whether FoF readings are the result of "subjectification", i.e. the diachronic process whereby "meanings become increasingly based in the speaker's subjective belief state/attitude toward the proposition" (Traugott $1989,31)$. On the one hand, this might well be suggested given the fact that the semantic change of modal verbs from deontic to epistemic meanings is treated as a prototypical case of subjectification. On the other hand, however, early instances of 'subjective' readings in German would be unexpected since the development of 'subjective' epistemic and evidential modal verb readings is commonly supposed to occur only after the 16th/17th century (see e.g. Fritz 1997; Diewald 1999; Maché 2008,387 for modal verbs in general; Gloning 2001,187 with respect to sollen + inf. in particular). Contrary to the latter assumption, FoF readings are already documented in Old High German (750-1050), see (10).

(10) Iz irgiangi thanne zi beziremo thinge, got ginádoti sin; léidor, thaz ni scólta sin. 'it would have turned out better, God would have been merciful to him; unfortunately, this not should be/was not to happen.'

[Otfrid: Evangelienbuch II, 6, 45f.]

In (10), the narrator first comments on Adam's fall into sin: If Adam had deliberated what he did, he would have propitiated God. The following sentence then forecasts with certainty what is to happen later in the story. Just as in the examples above, the evaluation does not only give a description of the events on the propositional level of the described events but also comments on the proposition as a whole on the interpersonal level, which is also indicated by the expressive adverb léidor ('unfortunately') that can only attributed to the narrator. Similarly, in (11) it is the narrator who comments on an event that will take place with certainty at a later time within the story.

(11) tho ward irfúllit thiu zit, thaz sáliga thiu álta thaz kind tho béran scolta. 'At that time, it came to pass that the blessed old woman should then give birth to the child?'

Are (10-11) thus early instances of 'subjective' epistemicity? They are in the sense that a difference between the propositional and the non-propositional level is indicated. Like the examples of FoF readings in present German above, (10-11) indicate the emergence of a narrator's viewpoint. As seen before, the high degree of certainty results from the structural position of the narrator's viewpoint on the higher level of discourse and not from an epistemic mental consciousness. In other words: It is not a person who assesses a high degree of likelihood for the 
realization of the event, based on his individual knowledge. Rather, the comment is the consequence of the control relations within the structure of discourse. FoF readings thus differ from 'subjective' epistemic meanings in that the former do not indicate an evaluating epistemic speaker's attitude. As such, they are not 'epistemic' in the narrow conception of the term.

What the early instances thus show is that reportive (i.e.: "I say that") and evaluative ('I claim for sure/probable ... that") meanings do not necessarily conventionalize hand in hand. In a wider context, this observation is relevant in two respects. First, it supports the claim made in the typological literature on evidentials that there is no inherent correlation between reportive constructions and degree of certainty. This is also argued for by Faller 2006 and Spronck 2012 who emphasize the importance "to separate the meanings of reporting a message and evaluating a message" (Spronck 2012).

Second, the observations have consequences for subjectification theory. As seen above, sollte shows an increase of subjectivity in the sense that a narrator's viewpoint outside the proposition emerges, while no epistemic belief state with respect to what is being said is indicated. This calls for a dissection of different kinds of '(inter)subjectification', as proposed e.g. by De Smet and Verstraete (2006); Smirnova (2012); Visconti (2013); Ghesquière, Brems and van de Velde (2014); Narrog (2017). If we take the discussion one step further, the differentiations between separate kinds of '(inter)subjectification' lead to the question of different kinds of 'subjectivity', as previously argued for by Bergqvist (2017). He differentiates a vertical axis between propositional and illocutionary level of meaning from the semantic content of the perspective on the horizontal axis and suggests that there is a multi-layered structure to illocution.

\section{Conclusions: Mechanisms of the emergence of multiple viewpoints and viewpoint interaction}

Turning back to the initial question about the general mechanisms of the emergence of multiple viewpoints and viewpoint interaction, the investigation of the particular instance of FoF constructions allows for the following conclusions.

Concerning viewpoint interaction in discourse, we have seen that the perspectival effect of FoF readings is not directly linked to a particular linguistic form but is the result of a complex interplay between the perspectival structure of the grammatical source construction and the perspectival structure provided by context, as seen in the blocking effect of FoF readings in Free Indirect Discourse. This conclusion is in line with Van Duijn and Verhagen (forthcoming) who show that multiple perspective constructions can be communicatively successful "when 
each of the deictic elements can find an 'anchor' in its context - however that is provided, by the co-text in a story, by a picture in a newspaper, etc.". In this respect, narrative discourse mode constitutes a specific context by structurally providing a covert viewpoint potential, so that the same grammatical items can allow for a different activation of viewpoints in narrative vs. non-narrative discourse.

Concerning the emergence of viewpoints, it has been argued that the appearance of the narrator's perspective can be seen as the result of an activation of a covert viewpoint potential as provided by narrative context. In consequence, it seems inadequate to describe the disambiguation of FoF readings in terms of perspective 'shifts'. Rather, it has been shown that the emergence of viewpoints for multiple viewpoint constructions and on the discourse level comprises several micromechanisms of perspectivization, i.e. a potential of alternative viewpoints, vertical and horizontal viewpoint shifts, viewpoint hierarchy and the integration of diverging perspectives under a superordinating viewpoint on a higher level of discourse. The relevance of the latter is also emphasized by Dancygier and Vandelanotte $(2016,14)$ who argue that the network constellation of multiple viewpoints is organized from "a top-level or 'Discourse Viewpoint' space, from which lower-level viewpoint choices are overseen".

The observations thus support, on the one hand, the necessity to take the whole perspectival arrangement into account, as argued in approaches that model perspectivization as network constellations (Dancygier and Vandelanotte 2016; Dancygier 2017; Van Duijn and Verhagen, forthcoming, and this issue). On the other hand, they have also shown the need to consider both the perspectival structure of the particular viewpoint construction as well as the viewpoint constellation of the given context. The ubiquity of viewpoints thus becomes apparent in two respects: on the micro-level of multiple perspective constructions as well as on the macro-level of discourse.

The hypotheses derived from the investigation of one particular instance of multiple perspective constructions have been demonstrated to be in line with previous approaches to perspectivization. While the generalizations made so far with respect to the mechanisms of network constellations call for further crosslinguistic examination, it has been made evident that a framework in perspectival terms is helpful in order to detect systematic dependencies between grammar and context within the semantics-pragmatics interface.

\section{Acknowledgements}

I would like to express my gratitude to the editors and two anonymous reviewers for their insightful comments and valuable suggestions. 


\section{Abbreviations}

$\begin{array}{ll}\text { ACT } & \text { active } \\ \text { DMV } & \text { deontic modal verb } \\ \text { EMV } & \text { epistemic modal verb } \\ \text { FID } & \text { free indirect discourse } \\ \text { FoF } & \text { future of fate } \\ \text { FUT } & \text { future } \\ \text { I } & \text { interval } \\ \text { IMPF } & \text { imperfective } \\ \text { INF } & \text { infinitive } \\ \text { P } & \text { proposition } \\ \text { PoV } & \text { point of view } \\ \text { PTCL } & \text { particle } \\ \text { SG } & \text { singular } \\ \text { te } & \text { event time } \\ \text { ts } & \text { speech time } \\ \text { TEL } & \text { telic. }\end{array}$

\section{Primary sources}

Deutsches Textarchiv. Grundlage für ein Referenzkorpus der neuhochdeutschen Sprache, Berlin, http://www.deutschestextarchiv.de/ (23.12.2018).

DWDS. Das Wortauskunftssystem zur deutschen Sprache in Geschichte und Gegenwart, Berlin, https://www.dwds.de (23.12.2018).

Homer: Iliad. Homeri Opera in five volumes. Oxford: Oxford University Press 1920. http:// www.perseus.tufts.edu/hopper/text?doc=Perseus:text:1999.01.0133 (23.12.2018).

Kali-Korpus, Leibniz Universität Hannover, http://www.kali.uni-hannover.de (23-12-2018).

Otfrid: Evangelienbuch. Edited by Oskar Erdmann. 6th edition, edited by Ludwig Wolff. Tübingen: Niemeyer 1973 .

\section{Refererences}

Abraham, Werner. 2008. "On the Logic of Generalizations about Cross-Linguistic AspectModality Links.” In Modality-Aspect Interfaces. Implications and Typological Solutions [Typological Studies in Language 79], ed. by Werner Abraham, and Elisabeth Leiss, 3-13. Amsterdam: John Benjamins. https://doi.org/10.1075/tsl.79.05abr

Abraham, Werner. 2012. "(Inter)Subjectification or Foreign Consciousness/Other's Mind Alignment as Synchronic and Diachronic Concepts of Change? Conceptualizations and Data Fidelity." In Covert patterns of modality, ed. by Werner Abraham, and Elisabeth Leiss, 24-78. Newcastle upon Tyne: Cambridge Scholars Publishing. 
Abraham, Werner, and Maiko Nisihiwaki. 2016. "Modal Verbs in German and Definiteness Effects in Verbal Complements - Focusing on Modern Standard German sollen and Middle High German suln 'shall'.' In Definiteness Effects: Bilingual, Typological, and Diachronic Variation, ed. by Susan Fischer, Tanja Kupisch, and Esther Rinke, 244-276. Newcastle Upon Tyne: Cambridge Scholars Publishing.

Allan, Rutger J. 2013. “Exploring Modality’s Semantic Space. Grammaticalization,

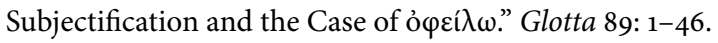

https://doi.org/10.13109/glot.2013.89.14.1

Banfield, Anne. 1982. Unspeakable Sentences: Narration and Representation in the Language of

Fiction. Boston: Routledge \& Kegan Paul.

Bassett, Samuel Eliot. 2003 [1966]. The Poetry of Homer. Lanham, MD: Lexington Books. Benveniste, Émile. 1966. De la subjectivité dans le langage. Problèmes de la linguistique générale, 1. Paris: Gallimard.

Bergqvist, Henrik. 2015. "Epistemic Marking and Multiple Perspective. An Introduction." STUF - Language Typology and Universals 68/2: 123-141.

Bergqvist, Henrik. 2017. “The Role of 'Perspective' in Epistemic Marking." Lingua 186/187: 5-20. https://doi.org/10.1016/j.lingua.2015.02.008

Bühler, Karl. 1999 [1934]. Sprachtheorie. Die Darstellungsfunktion der Sprache. Reprint Jena: Fischer. Stuttgart: Fischer.

Butt, John, and Carmen Benjamin. 2013. New Reference Grammar of Modern Spanish. London: Routledge. https://doi.org/10.4324/9780203783474

Dahl, Östen. 2006. "Future Tense and Future Time Reference." In Encyclopedia of Language and Linguistics, ed. by Keith Brown, 704-706. Amsterdam: Elsevier. https://doi.org/10.1016/Bo-08-044854-2/00253-4

Dancygier, Barbara. 2017. "Viewpoint Phenomena in Constructions and Discourse." Glossa: a Journal of General Linguistics 2(1), 37.1-22 [Special issue Perspective-taking, ed. by Stefan Hinterwimmer, and Petra B. Schumacher]: 1-22. https://doi.org/10.5334/gjgl.253

Dancygier, Barbara, and Lieven Vandelanotte. 2016. “Discourse Viewpoint as Network.” In Viewpoint and the Fabric of Meaning. Form and Use of Viewpoint Tools across Languages and Modalities, ed. by Barbara Dancygier, Wei-lun Lu, and Arie Verhagen, 13-40. Berlin/Boston: de Gruyter. https://doi.org/10.1515/9783110365467-003

De Jong, Irene. 2007. “Homer." In Time in Ancient Greek Literature. Studies in Ancient Greek Narrative, Volume 2, ed. by Irene de Jong, and René Nünlist, 17-38. Leiden: Brill. https://doi.org/10.1163/ej.9789004165069.i-542

Depraetere, Ilse. 2012. “Time in Sentences with Modal Verbs." In The Oxford Handbook of Tense and Aspect, ed. by Robert I. Binnick, 989-1019. Oxford: Oxford University Press.

De Smet, Hendrik, and Jean-Christophe Verstraete. 2006. "Coming to Terms with Subjectivity." Cognitive Linguistics 17: 365-392.

Diewald, Gabriele. 1999. Die Modalverben im Deutschen. Grammatikalisierung und Polyfunktionalität [Reihe Germanistische Linguistik 208]. Tübingen: Niemeyer. https://doi.org/10.1515/9783110945942

Diewald, Gabriele, and Mechthild Habermann. 2005. "Die Entwicklung von werden + Infinitiv als Futurgrammem: ein Beispiel für das Zusammenwirken von Grammatikalisierung, Sprachkontakt und soziokulturellen Faktoren.” In Grammatikalisierung im Deutschen [Linguistik - Impulse \& Tendenzen 9], ed. by Torsten Leuschner, Tanja Mortelmans, and Sarah De Groodt, 230-250. Berlin/Boston: de Gruyter.

https://doi.org/10.1515/9783110925364.229 
Duijn, Max van, and Arie Verhagen. Forthcoming. "Beyond Triadic Communication: a ThreeDimensional Conceptual Space for Modeling Intersubjectivity.” In Subjectivity and Stance. Usage-Based Studies in Epistemic Structuring, ed. by Dylan Glynn, and Karolina Krawczak. Amsterdam: John Benjamins.

Ducrot, Oswald. 1984. Le dire et le dit. Paris: Les éditions de minuit.

Eckardt, Regine. 2014. The Semantics of Free Indirect Discourse. How Texts Allow Us to Mindread and Eavesdrop. Leiden: Brill. https://doi.org/10.1163/9789004266735

Evans, Nick. 2005. "View with a View: Towards a Typology of Multiple Perspective Constructions." In Proceedings of the Thirty-First Annual Meeting of the Berkeley Linguistics Society, ed. by Rebecca T. Cover, and Yuni Kim, 93-120. Berkeley: Berkeley Linguistics Society.

Faller, Martina. 2006. "Evidentiality and Epistemic Modality at the Semantics/Pragmatics Interface." http://web.eecs.umich.edu/ rthomaso/lpwo6/fallerpaper.pdf (20.05.2018).

Fludernik, Monika. 1993. The Fictions of Language and the Languages of Fiction: The Linguistic Representation of Speech and Consciousness. London: Routledge.

Fritz, Gerd. 1997. "Historische Semantik der Modalverben. Problemskizze - Exemplarische Analysen - Forschungsübersicht." In Untersuchungen zur semantischen Entwicklungsgeschichte der Modalverben im Deutschen, ed. by Gerd Fritz, and Thomas Gloning, 1-157. Tübingen: Niemeyer.

Ghesquiere, Lobke, Lieselotte Brems, and Freek Van de Velde. 2014. "Intersubjectivity and Intersubjectification. Typology and Operationalization." In Intersubjectivity and Intersubjectification. Grammar and Discourse [Current Topics 65], ed. by Lieselotte Brems, Lobke Ghesquière, and Freek Van de Velde, 129-153. Amsterdam: John Benjamins.

Glas, Reinhold. 1984. 'sollen' im heutigen Deutsch. Bedeutung und Gebrauch in der Schriftsprache. Tübingen: Narr.

Gloning, Thomas. 2001. “Gebrauchsweisen von Modalverben und Texttraditionen.” In Modalität und Modalverben im Deutschen [Linguistische Berichte: Sonderheft 9], ed. by Reimar Müller, and Marga Reis, 177-200. Hamburg: Buske.

Halliday, Michael A. K., and Ruqaiya Hasan. 1976. Cohesion in English. London: Longman.

Hansen, Björn. 2009. “The Hypothetical Use of Polish 'mieć plus Infinitive' Revisited." In Von grammatischen Kategorien und sprachlichen Weltbildern - Die Slavia von der Sprachgeschichte bis zur Politsprache (Festschrift für Daniel Weiss zum 6o. Geburtstag) [Wiener Slawistischer Almanach, Sonderband 73], ed. by Tilman Berger, Markus Giger, Sibylle Kurt, and Imke Mendoza (eds.), 177-185. München: Kubon \& Sagner.

Holvoet, Axel. 2012. "Polish mieć and the Semantic Map of Interpretive Deontics." Zeitschrift für Slawistik 57/2: 129-146. https://doi.org/10.1524/slaw.2012.0009

Jakobson, Roman. 1957. "Shifters, Verbal Categories, and the Russian Verb." In Selected Writings 11, 130-147. Berlin/Boston: de Gruyter.

Kroon, Caroline. 1998. “A Framework for the Description of Latin Discourse Markers.” Journal of Pragmatics 30: 205-223. https://doi.org/10.1016/S0378-2166(98)00025-3

Kühner, Raphael, Friedrich Blass, and Bernhard Gerth. 1870. Ausführliche Grammatik der griechischen Sprache. Volume 2/1. Hannover: Hahn.

Łaziński, Marek. 2001. "Was für ein Perfekt gibt es im modernen Polnisch? Bemerkungen zum Artikel ,Gibt es ein Perfekt im modernen Polnisch?" von H. Weydt und A. Kazimierczak.” Linguistik online 8/1. URL https://bop.unibe.ch/linguistik-online/article/view/979/1637 (05.04.2018). 
Maché, Jakob. 2008. “The Autopsy of a Modal - Insights from the Historical Development of German." In Modality-Aspect Interfaces. Implications and Typological Solutions [Typological Studies in Language 79], ed. by Werner Abraham, and Elisabeth Leiss, 385-415. Amsterdam: John Benjamins. https://doi.org/10.1075/tsl.79.27mac

Markopoulos, Theodore. 2008. The Future in Greek. From Ancient to Medieval. Oxford: Oxford University Press. https://doi.org/10.1093/acprof:0so/9780199539857.001.0001

Narrog, Heiko. 2017. “Three Types of Subjectivity, Three Types of Intersubjectivity, their Dynamicization and a Synthesis." In Aspects of Grammaticalization. (Inter)Subjectification and Directionality, ed. by Daniël Van Olmen, Hubert Cuyckens, and Lobke Ghesquière, 19-46. Berlin/Boston: de Gruyter.

Öhlschläger, Günther. 1989. Zur Syntax und Semantik der Modalverben des Deutschen. Tübingen: Niemeyer.

Sanders, José. 1994. Perspective in Narrative Discourse. PhD thesis, Katholieke Universiteit Brabant.

Schrott, Angela. 1997. "Futur du passé im Französischen der Gegenwart.” Romanistisches Jahrbuch 48/1: 41-68.

Smirnova, Elena. 2012. "On Some Problematic Aspects of Subjectification." Language Dynamics and Change 2: 34-58. https://doi.org/10.1163/221058212X653076

Sperber, Dan, and Deirdre Wilson. 1986. Relevance: Communication and Cognition. 2nd edition. Oxford: Blackwell.

Spronck, Stef. 2012. "Minds Divided. Speaker Attitudes in Quotatives." In Quotatives. CrossLinguistic and Cross-Disciplinary Perspectives, ed. by Isabelle Buchstaller, and Ingrid van Alphen, 71-116. Amsterdam: John Benjamins. https://doi.org/10.1075/celcr.15.07spr

Spronck, Stef. 2015. "Stance as Participant Structure: A Jakobsonian Approach to the Pragmatics and Semantics of Evidentiality." In Evidentiality and the Semantics-Pragmatics Interface [Belgian Journal of Linguistics 29], ed. by Bert Cornillie, and Juana I. Marín Arrese, 193-216. Amsterdam: John Benjamins. Quoted version: http:// people.anu.edu.au/stef.spronck/publications.html (20.05.2018).

Sugayama, Kensei. 2006. “The Grammar of Be To: From a Word Grammar Point of View." In Word Grammar. New Perspectives on a Theory of Language Structure, ed. by Kensei Sugayama, and Richard A. Hudson, 90-108. London/New York: Continuum.

Sweetser, Eve. 2012. "Introduction: Viewpoint and Perspective in Language and Gesture, from the Ground Up." In Viewpoint in Language: A Multimodal Perspective, ed. by Barbara Dancygier, and Eve Sweetser, 1-22. Cambridge: Cambridge University Press. https://doi.org/10.1017/CBO9781139084727.002

Traugott, Elizabeth Closs. 1989. "On the Rise of Epistemic Meanings in English: An Example of Subjectification in Semantic Change.” Language 65: 31-55. https://doi.org/10.2307/414841

Traugott, Elizabeth Closs. 2003. "From subjectification to intersubjectification." In Motives for language change, ed. by Raymond Hickey, 124-139. Cambridge: Cambridge University Press. https://doi.org/10.1017/CBO9780511486937.009

Traugott, Elizabeth Closs. 2010. “(Inter)Subjectivity and (Inter)Subjectification. A

Reassessment." In Subjectification, Intersubjectification and Grammaticalization, ed. by Kristin Davidse, Lieven Vandelanotte, and Herbert Cuyckens, 29-71. Berlin/Boston: de Gruyter. https://doi.org/10.1515/9783110226102.1.29 
Verstraete, Jean-Christophe. 2005. "The semantics and pragmatics of composite mood marking: The non-Pama-Nyungan languages of northern Australia." Linguistic Typology 9: 223-268. https://doi.org/10.1515/lity.2005.9.2.223

Visconti, Jacqueline. 2013. "Facets of Subjectification." Language Sciences 36: 7-17. https://doi.org/10.1016/j.langsci.2012.03.016

Wakker, Gerry C. 2006. "Future Auxiliaries or Not." In Word Classes and Related Topics in Ancient Greek. Proceedings of the Conference on 'Greek Syntax and Word Classes' Held in Madrid on 18-21 June 2003, ed. by Emilio Crespo, Jesús de La Villa, and A. R. Revuelta (eds), 237-255. Louvain-la-Neuve: Peeters.

Wakker, Gerry C. 2007. "Intentions and Future Realisations in Herodotus." In The Language of Literature: Linguistic Approaches to Classical Texts, ed. by Rutger Allan, and Michel Buijs, 168-187. Leiden: Brill. https://doi.org/10.1163/ej.9789004156548.i-251.70

Zeman, Sonja. 2013. "Zur Diachronie der Modalverben: sollen zwischen Temporalität, Modalität und Evidentialität." In Funktionen von Modalität [Linguistik - Impulse \& Tendenzen 55], ed. by Werner Abraham, and Elisabeth Leiss, 335-336. Berlin/Boston: de Gruyter. https://doi.org/10.1515/9783110333091.335

Zeman, Sonja. 2014. “(C)Overt Modality and its Perspectival Effects on the Textual Surface." In Modes of Modality. Modality, Typology, and Universal Grammar [Studies in Language Complementary Series 149], ed. by Werner Abraham, and Elisabeth Leiss (eds.), 457-484. Amsterdam: John Benjamins. https://doi.org/10.1075/slcs.149.15zem

Zeman, Sonja. 2017. "Confronting Perspectives. Modeling Perspectival Complexity in Language and Cognition.” Glossa: a Journal of General Linguistics 2/1: 6 [Special issue Perspective-taking, ed. by Stefan Hinterwimmer, and Petra B. Schumacher]: 1-22.

Zeman, Sonja. 2018a. "Expressing the Selves: Subject Splits and Viewpoint Hierarchies in Multiple Perspective Constructions." In Expressing the Self: Cultural Diversity and Cognitive Universals, ed. by Minyao Huang, and Kasia M. Jaszczolt, 143-157. Oxford: Oxford University Press. https://doi.org/10.1093/oso/9780198786658.003.0008

Zeman, Sonja. 2018b. “Zukunft in der Grammatik: Neues vom Schicksalsfutur." In Die Zukunft der Grammatik - die Grammatik der Zukunft [Studien zur deutschen Grammatik 92], ed. by Elisabeth Leiss, and Sonja Zeman, 449-481. Tübingen: Stauffenburg.

Zeman, Sonja. 2018c. What is a Narration - And Why Does It Matter? In Linguistic Foundations of Narration in Spoken and Sign Language [Linguistics today/Linguistik aktuell 247], ed. by Annika Hübl, and Markus Steinbach, 174-206. Amsterdam: John Benjamins. https://doi.org/10.1075/la.247.08zem

Zeman, Sonja. Forthcoming. Wer spricht? Disambiguierungsfaktoren bei der Perspektivensetzung im narrativen Diskurs. Linguistische Berichte [Sonderband „Redeund Gedankenwiedergabe in narrativen Strukturen - Ambiguitäten und Varianz“, ed. by Stefan Engelberg \& Irene Rapp]. 


\section{Address for correspondence}

\section{Sonja Zeman}

Institut für Deutsche Philologie der LMU München

Schellingstraße $3 / \mathrm{RG}$

D-80799 München

Germany

Sonja.Zeman@lmu.de

\section{Biographical notes}

Sonja Zeman is an assistant professor at the Department for German Studies at LMU Munich. Her research interests include the semantics and pragmatics of verbal categories (ATME), historical discourse analysis, grammaticalization and semantic change. Currently, she is working on perspectivization in language from a cognitive-semiotic and diachronic point of view.

\section{Publication history}

Date received: 10 October 2018

Date accepted: 14 February 2019

Published online: 14 March 2019 